\title{
A COMPARISON OF MALAY AND TAMIL TRADITIONS SHADOW-PLAY
}

\section{${ }^{1}$ Samikkanu Jabamoney Ishak Samuel, ${ }^{2}$ Mahendran Maniam, ${ }^{3}$ Thinesh Subramaniam, ${ }^{4}$ Govindan Maruthai}

Tamil Language Programme, Sultan Idris Education University, 35900 Tanjung Malim, Perak, Malaysia ${ }^{1}$

English Language and Literature Department, Sultan Idris Education University, 35900 Tanjung Malim, Malaysia ${ }^{2}$

SMK Sandakan, Sandakan, Sabah, Malaysia. ${ }^{3}$

Tamil Language Programme, Sultan Idris Education University, 35900 Tanjung Malim, Perak, Malaysia ${ }^{4}$

Corresponding email: samjabarose@ yahoo.com.my

\begin{abstract}
The main objective of this study is to identify the similarities and differences between Malay and Tamil tradition of shadow-play. The design of this study is qualitative in nature using descriptive analysis methods based on Comparative literature theory. The researcher had collected and studied the similarities and differences in the Malay and Tamil tradition shadow-play. The findings of the study show that Malay and Tamil tradition of shadow-play have significant similarities in terms of story and form of puppets as the shadow-play in Malaysia have Hindu influences from Java or Pattani. However, many Malay shadow-plays have also been adapted and adopted to the culture and tastes of the local community, especially with the comic relief, that is often found throughout the Malay tradition of the shadow-play, as a local element. This comparative study will further strengthen the links between the Malay and Tamil communities that have co-existed for generations. The research claims to be the first such attempt to do a comparative study in finding the similarities and differences between Malay and Tamil tradition of shadow-play.
\end{abstract}

Keywords: shadow-play, comparisons, traditions, Malay and Tamil

Article Received: 18 October 2020, Revised: 3 November 2020, Accepted: 24 December 2020

\section{Introduction}

The earliest shadow-play existed in China and India at the same time. Chinese made shadowplays are spread to Mongolia, Persia and Central Asia. Whereas Indian shadow-play had spread to Indonesia, Burma, Cambodia, Vietnam and Thailand through the Chola Dynasty. The shadowplay that existed in northern India expanded into southern India including Tamil Nadu during the Maratha Dynasty that existed in Thanjavur in 1676 (Vengkadasamy, 1985).

Shadow-play is a very popular type of traditional theater among the people of Malaysia, India, Indonesia, Thailand, Cambodia and China. Shadow-plays are performed by utilizing the principles of light and shadow with puppets made up of various characters from the epic Ramayana and Mahabharata. The puppets are manipulated to movements by a conductor known as dalang. Performing a shadow-play is usually accompanied by a group of playful or graceful musicians as well as blasts or stringed instruments .
Shadow-play from every country has different features and functions. Although there are some commonalities in terms of story and the form of puppets in Malay and Tamil shadow-plays, many Malay shadow-plays have been adapted and adopted to the culture and tastes of the local community.

The shadow-play was invented some 5,000 years ago but had only been brought into Southeast Asia from India within the past few centuries along with the spread of Hinduism. The art of shadowplay is the story and stories taken from two of the largest and most famous Hindu scriptures, the books of Mahabaratha and the Ramayana.

Various forms and types of shadow-play are found in Asia and especially in Southeast Asia. Each type has its own form and characters and is quite different from one area or community background to another. The shadow-play of Thailand is called Nang Yai, Cambodia's is called Nang Sbek and in Java, it is called Purwa. In Malaysia, there are various types of shadow-plays such as 1516 
Kelantanese shadow-play, Malay shadow-play, Javanese shadow-play and Purwo shadow-play. In Johor it is known as purwo shadow-play and in Kedah and Perlis it is well known as the Gedek shadow-play. In addition, in Kelantan and Terengganu, it is well known as Kelantanese shadow-play. These shadow-plays differ from each other in their storylines and characters. Among these, the Kelantanese shadow-play is the most popular in Malaysia and it has become a worldwide hit. Although Malaysian shadow-play is not original to this country, as it is brought from Indonesia and Thailand, it is a national heritage, Shadow-play was first introduced into the country by the Malay community as a form of entertainment and folk arts during the 15th century AD.

Kelantanese shadow-play, which was brought into Kelantan through Patani, is believed to have originated in Cambodia and was subsequently widely distributed on the east coast of Peninsular Malaysia. The shadow-play was brought in to spread Islam to the locals, especially the Kelantanese. It was originally brought in by a preacher, known as the Wali Songo, who wanted to spread Islam to the people of Kelantan. Songo had thought of ways to spread the teachings of Islam among the local people at that time. As such, he had taken this shadow-play as a tool for spreading Islam and attracting locals to convert to Islam in the process (Mohamed Ghouse Nasaruddin, 2000).

In particular, information on Tamil shadow-play is found in the Tamil literature of the ninth century. But Tamil shadow-play only flourished during the Maratha dynasty in the seventeenth century. The reign of the Maratha dynasty had existed in Thanjavur, Tamil Nadu from 1676 to 1855. During that reign, many Maratha descendants including shadow-play puppeteers from northern India emigrated to Thanjavur. They initially held shadow-plays in the Marathi language. After learning Tamil, they began doing shadow-play in Tamil language. The Marathi descendants have not assimilated with the Tamils. They live as one of the most prosperous people in Tamil Nadu. They still speak Marathi. Nowadays, many Marathi puppeteers have settled in southern Tamil Nadu and they are able to perform shadow-play in the Tamil language.

\section{Research Problem}

The Malay and Tamil communities are two of the major societies in Malaysia. Both societies have their own culture and traditions. The Malay community is given the rights as the "people of the soil'. The Tamil people migrated from southern India during the British rule. Both societies have significant differences in language, religion and culture. However, the influence of Hinduism, before the Malay community embraced Islam, is still visible within the Malay community today. The influence of some elements of Hindu culture that are not in conflict with the teachings of Islam are still part of the culture of the Malay community. One of these cultures is the shadowplay. The widespread skepticism among the Malay community as a result of Hindu influence is still followed by the Malays. Shadow-play has also been very popular among Tamil people since the reign of the Maratha Dynasty in Tamil Nadu. Shadow-play is also part of the Tamil culture that is still prevalent in Tamil society. Although, shadow-play is part of the tradition in both the Malay and Tamil communities, there has been no comparative study in the area. Thus, this study was made to look at the similarities and differences found in the Malay and Tamil tradition of shadow-plays.

\section{Literature Review}

There are various thesis, books and research articles on shadow-play separately in Malay and Tamil. To date, ten undergraduate studies on Malay shadow-play have been conducted at several Malaysian universities. In addition, there are also articles related to shadow-play in Malay and Tamil. In the literature review section, the researcher elaborates on previous studies on 
shadow-play.

Fara Dayana Mohd Jufry (2018), conducted an undergraduate study entitled Traditional Malay Shadow-play (WKMTK): Archetypal Studies in Graphic Design at the School of Art, University of Science Malaysia. This study proves that Kelantanese traditional Malay shadow-play has high aesthetic value in terms of archetypal and the design of 'Gambalan'.

Khor Kheng Kia (2017), conducted a graduate study entitled 'Use of Computer Graphics (CG) in Capturing the Visual Styles of Kelantanese Shadow-play' in Multimedia university in Computer graphics. This research aims to study the use of Computer Graphics (CG) to capture the visual styles of WKK and contribute to its preservation.

Rosli Abd Manas (2009), conducted a master's study entitled 'Changing Values in Kelantanese Shadow-plays Before and During the PAS Government' at the Faculty of Languages, Sultan Idris University of Education. The findings show that shadow-play have undergone a change in the society of their supporters today as a result of changes in the values of Malay culture that have been traced through the aesthetics, education, political systems, technology and environment.

Duratul Ain Dorothy Jonathan Linggang (2009), a study conducted entitled 'Characters and Sculptures in Kelantan: A Study from the Aesthetic Corner' at the Cultural Center, University of Malaya. The findings of this study show that the characters and puppets have high aesthetic value in Kelantanese shadow-play.

Tan Kian Lam (2008) conducted a master study conducted entitled 'Real-Time Visual Simulation and Interactive Animation of Shadow-play' at the School of Computer Science, University of Science Malaysia. This study examines the shadow-play through visual simulation and interactive animation.

Nor Hazizan Talib (2008), conducted a master's thesis entitled 'Kelantan's Shadow-play from the Perspectives of Mysticism and Symbolism' at the Cultural Center, University of Malaya. This study shows that Kelantan's shadow-play is full of mysticism and symbolism.

Rahimi Saarani (2007), conducted a master's study entitled 'Elements of Conflict with Islamic Beliefs in Shadow-play: The Kelantan Government Steps to Address it from 1991-2002' in the Department of Islamic Creed and Thinking, Academy of Islamic Studies, University of Malaya. The findings of the study show that the Kelantan government has successfully dealt with elements that conflict with the Islamic faith in Kelantan.

Jamaludin Osman (2001), conducted a master's thesis entitled 'Illumination in Kelantanese Shadow-play' at Universiti Sains Malaysia. The findings of the study show that the role of the puppeteer is very important in the Kelantanese shadow-play.

Sugu Perinpam Joseph Kingham (1998), conducted a master's study entitled 'Symbolism in the Kelantan Shadow-play a Visual Aspect Study' at the School of Humanities Studies, University of Science Malaysia. The findings show that Kelantan's shadow-play has a unique symbolism in the visual aspect.

In addition, Ku Zam Zam Ku Idris (1978), conducted a master's study entitled 'Traditional Malay Music in Northern Kedah: Shadow-play Ensemble, Mek Mulung and Gendang Keling with a Focus on Instruments, Musicians and Functions' in the Faculty Literature and Social Sciences, University of Malaya. This study focuses on musical instruments, musicians and music functions on traditional performances such as shadow-play, mek mulung and gendang keling. In addition to the ten scholarly studies described above, there are also several articles related to Malay shadow-play. Dahlan Bin Abdul Ghani has written an article entitled 'Kelantanese Skinny Shadow-play: The Challenges between Traditional and Digital Media in Puppetry Theater'. This article discusses the challenges and 
future of Kelantan shadow-play in Malaysian society.

Fiona Wong E Chi and Ghulam-Sarwar Yousof (2018), have written an article entitled 'The Visual Elements in the Pohon Beringin Figure of the Kelantan Shadow Play'. This article examines the likely synthesis of conceptions related to mountains and trees in different belief systems (indigenous animistic, Hindu-Buddhist and Islamic) in the mountain or tree-shaped figure known as gunungan or kayon of the classical Indonesian shadow play Wayang Kulit Purwa and pohon beringin of the Malaysian Wayang Kulit Kelantan.

Ghulam-Sarwar Yousof and Kheng-Kia Khor (2017), have written an article entitled Kelantan's Shadow-play: 'A Study of Characterization and Shadow-play'. This paper examines the principal characters of the Malay versions (Hikayat Seri Rama and Hikayat Maharaja Wana) of the Hindu epic Ramayana, which provides the source material for the Malaysian shadow-play, the shadow-play Kelantan.

Fara Dayana Mohd Jufry and Mohd Kipli Abdul Rahman (2018), has written an article entitled 'Archetypal Characters in Kelantan Shadow-play'. The study specifically looks into the design aspects of the Kelantan shadow-play or locally known as Wayang Kulit Kelantan.

Apart from theses and articles there are also books related to the shadow-play in the Malay language by authors such as Ainu Sham Ramli (1996), Aziz Deraman, A. (2003), Fieda (2003), Haron Daud (2006), Hassan Othman (2004), Mohamed Ghouse Nasaruddin (2000), Samsiah Sabarudin (1993) and Ummi Abdullah (2003).

In addition to the Malay language books, there are also books on Tamil shadow-play authored by Ramanmoorthy, M.V. (1965), Ramasamy, M. (1983) and Vengkadasamy. (1985). These books tell the story of shadow-play in Tamil tradition.

\section{Research Methods}

The design of this study is qualitative with the method of descriptive analysis. Researchers have studied the similarities and differences in the Malay and Tamil tradition of shadow-play.

\section{Comparative Literature Theory}

Comparative literature theory is one of the disciplines of literary studies. Comparative literature theory exists in the interplay of human and international relations. This relationship creates a connection between one culture and another. Disciplines of textual study, literary history and literary criticism are the three literary research disciplines in comparative literature study.

Under the comparative literature theory, research, criticism and evaluation can be done between two authors, two groups of authors, two traditions or two regions. Thus, comparative literature attempts to find aspects of the similarities and differences between the two authors or the two traditions studied. Comparative literature in this aspect examines the nature, characteristics, position and so forth of looking at similarities and differences and the unique factors of an author or tradition.

In the study of "Puppet Shadow-plays A Comparison of Malay and Tamil Traditions", researchers will look at the similarities, differences and distinctions found in the Malay and Tamil traditional of shadow-play in terms of story content, presentation, opening ceremony, places of performance, characters, puppets, musical instruments, languages, methods of puppet making and the puppeteers.. This study is more about a theme, a thematic study. This study was done by analyzing and comparing the themes found in the shadow-play. Thematic studies found in the comparative literature discipline were used to find similarities and differences between the Malay and Tamil tradition shadow-play.

Authenticity, influence and continuity are three factors that are of the essence in comparative literary studies. Each tradition has its own originality inherited from their ancestors. Therefore, in this study the researcher intended to look at the distinctive features found in both Malay and Tamil traditional of shadow-play. 
Similarly, the element of influence is inevitable in the process of appreciation or development of an artistic tradition. The element of influence becomes an important theory that precisely aims to point out the concrete reasons why comparative literature is so important in examining and evaluating aspects of similarities and differences that can be traced to the origin of influence. There is no artistic tradition in the world that has survived the influx. Hence, the researcher wants to see the influence that has happened on both Malay and Tamil traditions of the shadow-play.

In comparative literature research, continuity is also one of the most important elements. The material similarities or associations between one art tradition and another tradition from the point of view of development or the changes experienced by one art are the meaning of continuity. The purpose of the study of the elements of continuity is to find out aspects or facts that have been passed down through time from one tradition to the next. Thus, this study seeks to prove the existence of similar elements of universality and the implications of environmental changes in the art of shadow-play between the Malay and Tamil traditions.

\section{Research Findings and Discussions}

In comparing the Malay and Tamil traditional shadow-play, the researcher has taken elements of story content, presentation, opening ceremony, places of performance, characters, puppets, musical instruments, languages, methods of puppet making and the puppeteers.

\section{Story Contents}

The story or episode usually played in the shadow-play is a Hindu religious tale of two wellknown epics, the Ramayana and the Mahabharata, which were given new breath by the Malay and Javanese masters. A. Aziz Deraman (2003) states that the development of art is strongly influenced by two great Indian epics, the Ramayana and the Mahabharata.
The contents of both the Kelantanese and Tamil shadow-play are almost identical because both traditions use the epic Ramayana. The distribution of episodes and the number of staging days alone differed between the Malay and Tamil traditional shadow-play. Kelantanese shadow-play uses stories from Hikayat Seri Rama. The Story of Seri Rama is a collection of stories that have been adapted from the epic Ramayana of Indian tradition. In the tradition of Malay shadow-play, stories from the epic Ramayana has about 30 episodes that impels the show to last for 30 nights (Ainu Sham Ramli \& Mohd. Azmi Ibrahim, 1996).

Tamil shadow-play also uses the epic of Ramayana. Since most Tamil shadow-play puppeteers are uneducated, they use the oral version of Ramayana. In Tamil shadow-play tradition, the Ramayana story is divided into 10 sections containing 189 episodes and is staged for 10 to 15 days. Apart from the story of Ramayana, Tamil shadow-play puppeteers also present the stories of 'Nallatanggal', 'Harichandran', 'Nyanasudari' and the likes. The Harichandran Story is one of the sub-stories of the epic Mahabharata (Ramasamy, M. 1983).

\section{Shadow-Play Presentations}

The presentations of the shadow-play in both Malay and Tamil traditions are very similar. The presentations in both traditions are divided into music, speech and gestures. Usually when the puppets talk, the music is stopped; minimal movement is made. This movement is done by moving the joints of the puppets' hand. Musical accompaniment is played when the puppets move, whether in travelling, going to war or otherwise.

Mohamed Ghouse Nasaruddin (2000), says that the use and pronunciation of a person's language is, in fact, determined by his teacher's knowledge and demands. In the context of the state of Kelantan, the pronunciation of the language differs according to the register or fluency that is inherited by a master from the original teacher. Even the Kelantan River itself is said to be a 
dividing line that gives two different forms of pronunciation and a completely different form of leather puppets. It is said that the forms of shadow puppets in the vicinity of kampongs Pasir Mas, Tumpat and Red Land are different to those of Bachok, Kota Bharu and Pasir Putih.

Perumal, A.K. (2003), states that a puppeteer's language and pronunciation depend on the location of the shadow-play. Tamil Nadu is divided into 32 districts and each district has its own dialect. The puppeteer will use the accent of the region in which the shadow-play is held. This is very similar to the use and pronunciation of 'Tok dalang" language in Kelantanese shadowplay.

\section{Opening Ceremony}

In the tradition of Malay shadow-play, every performance began with a spirit-worshiping solicitation that asked permission to invite the spirits to come to the crowd to celebrate the performance of the shadow-play. A total of 25 types of materials will be used during the recitations. After completing the recitations, the master puppeteer will signal his group members to play the opening song in which all musical instruments will be played simultaneously. After opening the stage, the young master will give a thirty-minute introduction of the story. Afterwards, the eldest puppeteer will tell the true story of Hikayat Seri Rama. The story will go on for two hours. In introducing a character in a Kelantan movie shadow-play, it is completely different from one puppeteer to another. Those skills and expertise make a huge difference. Even between a professional puppeteer and an amateur one, the term 'fake-puppeteer' has a vast positional difference (Surah Sabarudin, Surya Hafida Bahari, Zuzita Abdul Samad, 1993).

In the tradition of Tamil shadow-play, every performance begins with a prayer ceremony. The master-puppeteer will show one of these, the statue of the Vinayaga, Goddess Lechumy or Goddess Saraswathy, in colours besides singing the hymn of the deity or goddess for two or three minutes. Later, a comic character will appear to present a joke. After that, the puppeteer will begin the true story of the epic Ramayana. In the middle of the story, the puppeteer will stop the story from the epic Ramayana and hold a five or ten minute joke scene. After that, the puppeteer will continue the Ramayana story until the end of the story for the night (Perumal, A.K. 2000).

\section{Venues}

The Malay and Tamil tradition shadow-play performances are almost identical. The traditional Malay shadow-stage theatre is made of wooden poles with walls and roofs made of rumbia or nipah. Usually the stage is built three or four feet from the ground and is a hut that can house the stage of shadow-play, the musicians and the instruents of the shadow-play. The front of the stage is fitted with a piece of white cloth called the color (screen) and on the back of it is a light (in the past a kerosene lamp, but an electric light at present). Banana tree stems are laid next to the screen to stick the puppets (Mohamed Ghouse Nasaruddin, 2000).

In ancient times there were rituals for purification and setting of stage. The purpose is to worship the evil spirits of the staging area. On the appointed day, a shaman or medium would bring four semicoconut shells of the sprouting side to the stage. Each of these shells contain iron-ore, charcoal, spoilt belacan, black pepper, salt and tumeric roots (Mohamed Ghouse Nasaruddin, 2000).

The shaman or medium holds the shells with its contents to a spiralling smoke of benzoin before they are inserted clockwise in the holes of the four poles of the stage, beginning with front porch. The ceremony ends with a small feast for the puppeteers and the workers. Subsequently, workers continue the work of completing the stage by constructing floors, walls and roofs. Usually a fifth pillar, known as the holy pillar, is built in the middle of the stage, not as a rooftop but as a hanging one for the master's rice, a meal in honor of Master Batara. This dish contains yellow rice 
and side dishes wrapped in white cloth (Mohamed Ghouse Nasaruddin, 2000).

The Tamil shadow-play was originally built as a Malay shadow-play. After the performance, the women will use the stage as the bed. This is because in the past all the families of the puppeteers practiced a life of wandering. The whole family moved from one place to another to perform their shadow-plays. The puppeteers' family do not have a home of their own. Their families slept on the stage or in their wagon. They only have one bullock-cart to move around with their necessities. This has made their children to be uneducated (Ramasamy, M. 1983).

In modern times Tamil shadow-play stages are made from knock-down metal structures. Today, every Shadow-play group has a ready-made tent. They no longer practice the life of wandering. Now Tamil shadow-play families have permanent homes and their children are able to attend school. The puppeteer and the members of his group do their performance only on invitations (Ramasamy, M. 1983).

\section{Characters}

The characters in the Malay and Tamil traditions are also very similar. In the shadow-play of both traditions, the characters are divided into main characters, sub-characters and comedians. The main characters in both traditions are, Seri Rama, Dewi Sita, Hanuman, Lakshmana and Emperor Rawana. The sub-characters usually are Ang Nila, Ang Gada, Pateh Jambu, Sagariwa and Mah Babu Sanam. The main characters and sub-characters in both the shadow-plays are the same as the epic Ramayana is the same in both traditions. The characters are divided into two: the evil and the good (Patricia Matuskym, 1997).

In the Malay tradition the comic characters are Pak Dogol, Wak Long, Wak Yah, Samad and Said. In the Tamil shadow-play tradition the comic character is known as Kundotaran, Uluva Talaiyan, Uchikudumpan and so forth. However, in both traditions, the comic character is a local character with local characteristics included to create joke scenes.

The characters of Pak Dogol and Wak Long have two hands and a chin that can be moved. While the other puppets have only one hand that can be moved with the fine bamboo sticks attached to the hand. These puppets are painted in fine and bright colours. Different colours reflect different character traits. Color differences also distinguish characters with similar shapes. For example, Sri Rama and Laksamana. Red and green are painted on Sri Rama puppets while Lakshmana is painted red on the body and gold on the face (Patricia Matuskym, 1997).

Usually, black brings a symbol of grandeur and maturity. Red color, patience and courage. Yellow for royal groups, and white for authoritative and ethical people. Multiple color combinations are used to describe the general characteristics of a character (Patricia Matuskym, 1997).

\section{Puppets}

Decorative carvings of Malay and Tamil traditional puppets are also very similar. In the traditional Malay shadow-play puppets, only the hands in the foreground can move while holding weapons or other paraphernalia. For Tamil shadow-play puppets both hands can move. In both traditions, good-natured puppets often lower their heads, and their bodies are small and beautiful. Stubborn and arrogant puppets are usually large-nosed, have fierce teeth with an upward look. In terms of color the fierce characters are colored heavy and dark.

The size or the size of a statue is determined by its type and character, but it does not exceed 28 inches tall and 15 inches wide. Fine characters like Sri Rama and Lakshmana are smaller and more densely carved than other puppets or other evil characters. Hanuman is a handsome character with a stout face. But the two comedians or nanny, Pak Dogol and Wak Long are different from the rest. They are smaller in shape with no carvings or with basic work and are painted black. The simplicity of these forms is indicative of their 
mystical character and purity (Zabri Zakaria, 2005).

There is another important statue of Kekayon, Mountains or Beringin Tree statue. It is shaped like a leaf and within it contains stylish trees, flowers, birds, apes and other animals. It is flanked by a pair of animals, be it a pair of tigers, lions and elephants, a pair of wild cattle or other combinations (Zabri Zakaria, 2005).

The tree or mountain in the Mountains represent two mystical symbols of Hinduism. One is the Tree of Life which protects and sustains all the animals carved on its face. It is also a symbol of 'The Celestical Wishing Tree of Myth' which is symbolized by the figure of sun. Another is the mountain which refers to the mystical mountain of the gods and the mountain of the world known as the Mahameru to the Hindus (Zabri Zakaria, 2005).

In the traditional Malay shadow-play, almost all the puppets depict features of Javanese and Thai influences that retain their original features in terms of clothing, headscarf and armaments. But in the Tamil shadow-play, almost all of the puppets have Indian features.

\section{Musical Instruments}

In the traditional Malay shadow-play, the use of musical instruments to stage a performance is a combination of some traditional Kelantanese musical instruments that are played live according to the instructions and stories played by the puppeteer. The role of music is immensely successful in a complete performance. Musical rendering provides ritual, dramatic and structural functions. Structural functions can be seen before the beginning of the performance when a musical group plays a few songs to inform the audience that the performance is about to begin. During the performance of the story, music marks the entry and exit of all the important characters (Patricia Matuskym, 1997).

Music provides a dramatic function by creating a variety of moods required for specific purposes in the stories such as grief, joy, happiness and violence. All fights and wars are accompanied by War Songs and music accompanies all the songs in the show. Its spiritual function is to produce a rhythmic and magical atmosphere during the opening and closing ceremonies and the change of the puppeteers (Patricia Matuskym, 1997).

The ensemble cast provides music with instruments such as the Aerophone ensemble, a joyous melody. Membranophone ensemble involves a pair of geduk,. In addition, drums known as gendang come in pairs, also with a larger ibu and a smaller anak. Another pair of drums is the gedumbak with the ibu and anak of almost similar in size. There is also an Idiophone group of musical instruments, which is a pair of canang, ibu and anak. The ibu is higher in pitch than the anak. Then, there is the pair of ibu and anak in the instruments of kesi and tetawak. The pitch of the anak tetawak is higher than the ibu. Each of these instruments has different functions. The serunai plays the melody, the three types of drums provide rhythm, while the idiophone group divides the song into periods of time. At the end of the performance, music is played to indicate the performance is complete (Patricia Matuskym, 1997).

In Tamil shadow-play, music also plays an important role in the performance of the shadowplay. Musical instruments such as patakaddai, pavar, jaalra, miruthangam and suthipetti are used in the performance. The patakaddai is tied to the feet and the sound is made as the story progresses. Pavars are used to produce various animal sounds such as the sounds of horses, elephants and tigers (Ramasamy, M. 1983).

In both Malay and Tamil traditions, musical instruments play an important role in the shadowplay. Musical instruments are played to create a variety of moods required by specific stories such as grief, joy, happiness and violence. There is only difference in the type of musical instrument between the Malay and Tamil traditions.

\section{Languages}


In the Malay shadow-play tradition, 'tok dalang' uses Kelantanese Malay dialect. Sometimes foreign languages like Hindi, Chinese and Tamil as well as English are mixed in to create an atmosphere of entertainment while communicating information. In the Tamil shadowplay tradition, Tamil language is used as a medium of communication. The puppeteers also use the local dialect of the district where they present the shadow-plays. For example, if a puppeteer performs a shadow-play in Tirunelveli district, he will use the Tamil dialect of Tirunelveli district.

\section{The Making of the Puppets}

In both Malay and Tamil traditions, the puppeteer is the person responsible for making the performing puppets. A puppeteer has to have the creativity and ingenuity to create his own characters and every character he creates should have an interesting art design that is appropriate to match the story he wants to present. In the Malay tradition the puppets are made of cow leather but in the Tamil tradition the puppets are of goat or deer skin.

The flayed cow or goat's skin is cleaned and soaked in salt water, pepper, ginger, and lemongrass for several days and then dried by pinning its corner to a board. Once the skin is completely dried and becomes odorless, the hair on the dry skin is removed by scrubbing with glass pieces until it is clean. A paper drawing with the face of the character is stuck to the skin that has been cleaned. This is where the creativity and the mastery of the puppeteers are shown to create the puppet-doll that they want to use in the performance. Each piercing and carving have specific functions and the characters produced have their own aesthetic identity (Perumal, A.K. 2000).

Bamboo as the rigid frame is carefully splayed and fastened with string to the skin that is ready to be pierced. Cord is used to create movement on the lips, hands and other parts needed for the statue. This cord is tied once the puppet has been colored according to the characters depicted in the specific stories. The most commonly used color mediums are dye fabric and watercolor. The work of painting the puppets requires immense creativity, talent and patience (Ramasamy, M. 1983).

\section{Tok Dalang The Puppeteer}

In both Malay and Tamil traditions, the puppeteer is the leader in a shadow-play. The puppeteer is an important person who plays a major role in a shadow-play. $\mathrm{He}$ is the person responsible for reviving the characters of the moving puppets. The puppeteer must be someone who is good at story-telling by following the music and being able to change the voice according to the character of the statue. In order to be a good puppeteer and good at captivating the audience, one must be able to tell the story and to control his voice well. A good change of voice according to the character will make the audience feel better (Jamaludin Osman, 2001). Obviously, the shadow-play allows the puppeteer to respond to the audience's wishes. There is a difference among the puppeteers themselves. There are mainland puppeteers and inland puppeteers. The former is an expert and better in the rendition of the storyline and the presentation, in comparison to the latter. The puppets used by the former are also exotic and their movements are very quick and fast. In addition, mainland puppeteers use modern musical instruments such as organs in place of the serunai. There are also some puppeteers who use popular Hindi music to enliven the atmosphere and thereby keeping the audience for longer performances. However, there are times when mainland puppeteers over-mimic the performance techniques of others, the show leads to boredom (Jamaludin Osman, 2001).

In contrast to the mainland puppeteers, the inland puppeteers always balance their presentations according to the audience's wishes. The featured art is original and pure without any imitation elements in the show. The performances are so meticulous and refined that it captures the 
attention of audiences who love this art of shadow-play (Jamaludin Osman, 2001). Usually there are elements of suspense at the end of the show that make the audience wonder and subsequently wait to see the end of the story, though made on different days; they simply want to know more about the story.

\section{Conclusions}

Basically, all forms or types of shadow-play available in Malaysia have Hindu influences from Java or Pattani but their development has caused them to adapt and adopt according to their acceptance within the context of the local community. This is because shadow-play is essentially a community communication tool as well as an art form. The storylines, the shapes of the puppets and characters still retain their origin and influence but with the comic relief often found throughout the puppet story, it evokes local linguistic elements and events as well depicted. In conclusion it can be said that the Malay and Tamil traditions of shadow-plays are almost similar with minimal differences.

\section{Limitation And Study Forward}

Malay shadow-play is made up of four types, such as Kelantanese shadow-play, Malay shadow-play, Purwa shadow-play and Gedek shadow-play. In this research, the researcher only took Kelantanese shadow-play for comparison to Tamil shadowplay.

\section{Acknowledgement}

The author thanks the Sultan Idris University for giving him a grant to a worth of RM5000.00 to study about. Malay and Tamil tradition shadowplay. This grant has helped the author to produce this article.

\section{References}

[1] Aziz Deraman, A. (2003). Masyarakat dan Kebudayaan Malaysia. Kuala Lumpur: DBP.
[2] Fieda. (2003). Permainan Wayang Kulit. Selangor: Oak Enterprise.

[3] Fiona Wong E Chi dan Ghulam-Sarwar Yousof. (2018). Malaysian journal of performing and visual Arts, volume 4, 2018.

[4] Ghulam-Sarwar Yousof and Kheng-Kia Khor. (2017). Asian Theatre Journal. University of Hawai'i Press. Volume 34, Number 1, Spring 2017.

[5] Haron Daud. (2006). Artikel berjudul "Teater Tradisional Untuk Hiburan?" dalam Dewan Bahasa, April 2006.

[6] Hassan Othman. (2004). Wayang Gedek. KL: Kementerian Kebudayaan, Kesenian dan Warisan Malaysia.

[7] Jamaludin Osman. (2001). Pendalangan di dalam Wayang Kulit Kelantan. Pulau Pinang: Universiti Sains Malaysia

[8] Jufry, F. D. M., \& Rahman, M. K. A. (2018). Archetypal Characters In Wayang Kulit Kelantan. International Journal of Academic Research in Business and Social Sciences, 8(5), 87-101. http://dx.doi.org/10.6007/IJARBSS/v8$\underline{\mathrm{i} 5 / 4087}$

[9] $\mathrm{Ku}$ Zam Zam Ku Idris "Alat-Alat Muzik dalam Ensembel Wayang Kulit, Mek Mulung dan Gendang Keling di Kedah Utara" makalah dalam buku Kajian Budaya dan Masyarakat di Malaysia disusun oleh Mohd Taib Osman dan Wan Kadir Yusof (1983) Kuala Lumpur: Dewan Bahasa dan Pustaka.

[10] Mohamed Ghouse Nasaruddin. (1997). Wayang Kulit Dalam Era Globalisasi. Kuala Lumpur: Kementerian Kebudayaan, Belia dan Sukan Malaysia.

[11] Mohamed Ghouse Nasaruddin. (2000). Teater Tradisional Melayu. Kuala Lumpur: Dewan Bahasa dan Pustaka.

[12] Mohamed Ghouse Nasaruddin. (2005). Artikel berjudul "Komunikasi dan Estetika dalam Teater Tradisional" tersiar dalam majalah Dewan Budaya November 2005. 
[13] Patricia Matuskym. (1997). Malaysian Shadow-play and Music. Penang: The Asian Centre.

[14] Perumal, A.K. (2000) Ramayana Thol Pavai Kuttu. Chennai: Penerbit Pumpukaar.

[15] Perumal, A.K. (2003). Tholpavai Kuttu. Chennai: Penerbit Pumpukaar.

[16] Ramanmoorthy, M.V. (1965). The Art and Tradition of Shadow Puppet Show in India. Madras: Bulleit of the Institute of Tradisional Cultures.

[17] Ramasamy, M. (1983). Tholpavai Nilalkuthu. Madurai: Madurai Kamarasar Palkalaikalakam.

[18] Ramli, A. S., \& Mohd. Azmi Ibrahim. (1996). Wayang kulit: warisan teater Melayu. Perbadanan Kemajuan Kraftangan Malaysia.

[19] Samsiah Sabarudin, Surya Hafida Bahari, Zuzita Abdul Samad(1993). Wayang Kulit. Kuala Lumpur: Pustaka Bakti Wira.

[20] Ummi Abdullah. (2003). Wayang Kulit. Kuala Lumpur: Kementerian Kebudayaan dan Kesenian dan Pelancongan Malaysia.

[21] Vengkadasamy. (1985). Pavai Kuttu. Sivakangkai: Annam Veliyidu.

[22] Zabri Zakaria (2005). Persembahan Tradisional: Variasi dan Budaya. Selangor: Sejati Books. 